\title{
THE REQUIREMENTS FOR ENTITLEMENT TO UNEMPLOYMENT BENEFIT
}

\author{
DOI: 10.17261/Pressacademia.2018.1010 \\ RJBM- V.5-ISS.4-2018(4)-p.262-270
}

\section{Volkan Gunes ${ }^{1}$, Arzu Hacioglu²}

${ }^{1}$ Istanbul Technical University, Faculty of Management, Department of Management Engineering, Macka Campus, İstanbul, Turkey. gunesv@itu.edu.tr, ORCID: 0000-0002-1713-8204

${ }^{2}$ Istanbul Technical University, Faculty of Management, Department of Management Engineering, Macka Campus İstanbul, Turkey haciogluar@itu.edu.tr, ORCID: 0000-0003-1652-4012

Date Received: October 20, 2018

Date Accepted: December 24, 2018

To cite this document

Gunes, V., Hacioglu, A. (2018). The requirements for entitlement to unemployment benefit. Research Journal of Business and Management (RJBM), V.5(4), p.262-270.

Permemant link to this document: http://doi.org/10.17261/Pressacademia.2018.1010

Copyright: Published by PressAcademia and limited licenced re-use rights only.

\begin{abstract}
Purpose - Turkish lawmaker adopted unemployment insurance with Law numbered 4447 in 1999 . This study aims to scrutinize the conditions for benefitting from unemployment insurance, with the focus on the unemployment insurance payment. By studying on this, we want to bring some clarity to the practitioners.

Methodology - The conditions for benefiting from unemployment insurance payment will be examined in the light of Court of Cassation's judgment and practice of Turkish Employment Agency in a comparative law approach. With this regard, we will refer to German Law which has a solid system of unemployment insurance.

Findings - Unemployment benefit is granted only to unemployed insured whose employment contract is terminated on certain grounds and who has sufficient premiums. The requirements to be met for benefiting unemployment insurance are harsh, therefore they exclude majority of the unemployed persons.

Conclusion- Although the scope of unemployment insurance has been extended recently, unemployment insurance alone is not sufficient to combat unemployment.
\end{abstract}

Keywords: Unemployment insurance, unemployment insurance fund, unemployment benefit, employee, employer. JEL Codes: K31, K41, J41

\section{INTRODUCTION}

Unemployment is one of the social risks listed in the ILO Convention No. 102, which was adopted in 1952 and set minimum norms on social security. Although the number of countries adopting compulsory unemployment insurance in their social security systems increased with the Convention No. 102, these developments took place at a relatively late date in our country (Güzel/Okur/Caniklioğlu, 2016: 669). For our country, the Convention has been in force since 1975, certain reservations to the provisions regarding unemployment were made though. Although this negative approach for unemployment insurance continued for many years, the Unemployment Insurance Law No. 4447 was entered into force on 25.08.1999. Unemployment insurance benefits provided for in the Law No. 4447 are unemployment benefits, vocational training and assistance for finding job, social insurance premiums paid by Turkish Employment Agency ("iŞKUR"). Since Law No. 4447 envisages an employer-employee-state funded compulsory unemployment insurance; in other words, the system is based on social insurance technique; there is no social assistance as a result of a non-contributory system. Unlike in other European countries, our social security system does not provide any unemployment benefits that could be qualified as a social assistance. In Germany as an example of an advanced social security system, both unemployment benefit named "Arbeitslosengeld I (Alg I)" and unemployment assistance named "Arbeitslosengeld II (Alg II)" or commonly known as "Hartz IV" are regulated clearly with law.

In our social security system where there is no unemployment benefit in the nature of unemployment assistance, income assurance is provided to unemployed persons by unemployment benefit as a requirement of social state. In this context, unemployment benefit is of particular importance among the other unemployment insurance benefits. Because the unemployment benefit is the most important tool in terms of ensuring a group, expressed in millions in our country, can 
live a decent life. Turkish Statistical Institute ("TÜiK"), recently announced the unemployment rate at $11.1 \%$ on 15.11 .2018 and has reported that this rate corresponds to 3 million 670 thousand people (TÜiK Newsletter, No. 27690). It should be noted that this ratio is quite high compared to European countries. For example, according to the latest data from the Federal Statistical Office of Germany, the unemployment rate in the country is only $4.9 \%$ (https://www.destatis.de/DE/ZahlenFakten/Indikatoren/Konjunkturindikatoren/Arbeitsmarkt/arb210.html). In our country, it is very important to determine the requirements for benefitting from unemployment benefit since there is no unemployment benefit within the concept of social assistance and the number of the persons constituting the interest group, in other words unemployed is very high. We have dedicated our work to the requirements of entitlement to unemployment benefit due to this importance.

In our country, the requirements for benefitting from unemployment benefits could be considered severe. The requirements for entitlement to unemployment benefit will be explained in detail below, but statistical information can demonstrate the level of severity. All the payments, including unemployment benefit provided for by Law No. 4447, are made from Unemployment Insurance Fund. As of October 2018, the Fund's revenue was over TL 125 billion and the total payment made up to now is just over TL 22 billion. Currently, the number of people benefiting from unemployment insurance payments is 476.097 (iŞKUR Unemployment Insurance Fund Newsletter, October 2018). Considering the abovementioned unemployment rate and the corresponding number of people, it is clear that the rate of entitlement to unemployment benefit is low. In order to support this striking finding, in the "100-Day Action Programme" announced on 03.08.2018 by the Presidency, it is clearly stated that the requirements for the entitlement to insurance benefit will be stretched. In this context, stretching the requirement of certain length of working period and the premium, which will be explained in detail below, are on the agenda (See. http://www.hurriyet.com.tr/ekonomi/issizlik-maasina-yeni-duzenleme40934573, https://www.haberturk.com/son-dakika-haberler-issizlik-maasi-kosullari-esnetiliyor-issizlik-maasi-nasil-alinir2242438-ekonomi).

In this study we aim to scrutinize the requirements for entitlement to unemployment benefit. We will focus on the scope of persons considered "insured" first. Then we would like to define "unemployed" person within the meaning of Law No. 4447. The grounds for termination of employment contract that may grant this benefit will also be examined thoroughly. Lastly, we will evaluate premium and application requirements.

\section{BEING INSURED}

Although the unemployment insurance in our country was regulated by Law No. 4447, the insured persons were determined by reference to the Social Insurance and General Health Insurance Law No. 5510. However, not all the insured persons listed in the Law No. 5510 are covered by unemployment insurance. In principle, only insured persons who work under employment contracts can benefit from unemployment insurance. Civil servants and other public officials cannot benefit from unemployment insurance, as well as apprentices and interns as those do not work with employment contracts. Apart from that, those who work independently on their own behalf and not subject to employment contracts are also not covered by the unemployment insurance scheme (Art. 46/ II of Law No. 4447 with reference to art. 4 of Law No. 5510). It is necessary to add that with the adoption of additional article 6 to the Law No. 4447 in 2017, a group of the independent employees were included in the "unemployment" insurance by associating them with the "Esnaf Ahilik Sandığı" (Tuncay/ Ekmekçi, 2017: 652-653).

In order to benefit from unemployment insurance, it is necessary and sufficient to have worked with the employment contract within the scope of Law No. 5510. The employment of the insured employee in the private or public sector, or whether they are subject to the Labour Law No. 4857, is not important in terms of benefiting from unemployment insurance.

The fact that the insured person is foreign does not prevent him/ her from benefiting from unemployment insurance. However, either foreigners or Turkish citizens sent to Turkey for the period not exceeding 3 months do no fall within the scope of unemployment insurance as long as they are insured in a foreign country and can document this. In spite of that, insured persons who are sent abroad by their employers are covered by unemployment insurance. However, these people can only get unemployment benefit if/ when they return to Turkey (Art. 48/ VIII of Law No. 4447).

The type of employment contract has no importance with respect to benefit from unemployment insurance. Insured persons may work under a definite or indefinite term employment contracts or they fall within the scope of unemployment insurance even if they work with full- time or part- time employment contracts (Caniklioğlu, 2011: 10). However, meeting the premium payment days required to benefit from unemployment benefit may be difficult for the insured persons working with part- time employment contracts. The lawmaker who does not disregard this issue, has accepted that those persons may opt for voluntary insurance for the days remaining in the month (Art. 50 of Law No. 5510); in this context, they may be insured for the periods of non-employment (Art. 46/ II of Law No. 4447). Similarly, those who are employed in commercial taxi and similar urban public transport vehicles and those who work under the part time employment contracts 
in areas to be determined by the Ministry of Culture and Tourism for less than 10 days in a month, can pay unemployment premium if they wish (Art. 46/ II of Law No. 4447 with reference to the additional art. 6 of Law No. 5510).

The scope of the unemployment insurance includes the insured persons subject to the "pension funds" listed in the provisional article 20 of the Social Insurance Law No. 506 (Art. 46/ II of Law No. 4447). However, persons associated with such funds founded by banks, insurance and reinsurance companies, chambers of commerce, chambers of industry, stock exchanges can only be accepted within the scope of unemployment insurance as long as they work under employment contracts.

\section{BEING UNEMPLOYED}

The second requirement of entitlement to unemployment benefit is to be unemployed. In article $47 / \mathrm{I} /$ e unemployed insured is defined as "the person who lost his/ her job due the reasons stated in the relevant articles of this Law while working as insured under employment contract in a workplace within the scope of this Law and notified that he/ she is ready to work by applying to the Agency". Again, in order to specify the components to be used in the determination of the unemployment phenomenon, the same clause of the same article to which unemployment insurance is defined should be taken into consideration. "Will and the ability of work" is clearly stated herein. In addition, in article 51 of the Law regulating the requirements for qualifying unemployment benefit, the necessity of insured to make a registration regarding that he/ she is ready to work by applying to işKUR is stated. Based on these regulations, it is useful to examine the phenomenon of unemployment in the context of three components. These are; not to work, but to be willing and able to work. As a matter of fact, in comparative law, unemployment is examined in the context of these three elements. In Sozialgesetzbuch (SGB) III § 138 in German Law, there are three conditions for unemployment. The first of these is not to be in a working relationship which could be briefly defined as non-working (Beschäftigungslosigkeit), the second one is to make effort to end the state of unemployment that we can describe as being willing to work (Eigenbemühungen) and third one is to be available for the job replacement service of Federal Employment Agency briefly defined as availability (Verfügbarkeit). In terms of our legislation, although the conditions for the phenomenon of unemployment are not listed systematically unlike German Law (see SGB III § 138), according to the above-mentioned regulations, in order to establish unemployment phenomenon which, entitles unemployment benefit, non-working and yet being willing and available of work requirements should be valid for our law, too. Therefore, in this study, unemployment phenomenon which is one of the requirements for the entitlement of unemployment benefit will be examined within the context of following components: absence of working relationship, willingness to work and availability to work.

\subsection{Absence of Working Relationship}

First of all, the classic and most general appearance of the absence of working relationship constitutes the end of the employment contract. In this context, it will be explained below which of the types of termination of employment contract will be entitled to unemployment benefit. However, it should be examined here whether the wording of "losing job while working" in the definition of unemployed insured in Law No. 4447 exclude all kinds of work time-wise. It should be noted that even if the daily or weekly working time is too short, it is not possible to accept that the non-working condition has been met, therefore unemployment phenomenon cannot be established. Again, in article 52/ I / b of Law No. 4447 as a support abovementioned conclusion- it is stated that if the unemployed insured receiving unemployment benefit works in an income-generating job; unemployment benefit would be interrupted. However, in comparative law, there are examples where this condition is more flexible. For example, in SGB III $\S 138 / 3$, it is clearly defined that employees who work under 15 hours weekly can be entitled to Alg I as unemployment benefit under German Law. At this point, we would like to emphasize that there is no difference between working dependently or independently (Baldschun, 2018: SGB III § 138 Rn. 67; Koch, 2017: § 23 Arbeitslosengeld I Rn. 6; for a different approach see Hekimler, 2008: 541).

A special problem needs to be considered in the absence of a working relationship is the case when the employment contract is suspended. Article 51 of Law No. 4447 lists the suspension situations as strike, lockout or duties arising from law as to prevent the entitlement to unemployment benefit. The suspension of employment contract results in suspending the main obligations of employer and employee, namely work and wage, while the employment contract itself and the other obligations arising from it remain (Süzek, 2018: 492). It is not possible for us to adopt an inclusionary approach in terms of the question of whether all suspension cases will entitle the unemployment benefit. The fact that the law maker has only included the cases of suspensions related to strikes, lockouts or duties arising from law and the wording of the article in question itself support this. In the event of a suspension, whether the insured could be regarded as unemployed should be assessed separately within the context of each condition for unemployment. It can be said that the insured does not have a working relationship in cases of the strikes, lockouts or duties arising from law that result the suspension of the employment contract (For similar evaluations in German Law, see Brand, 2018: SGB III § 138 Rn. 18). Undoubtedly, the most important indicator of the existence of a working relationship is the existence of personal dependence and the authority of the employer. Such a situation cannot be observed in cases of the strike, lockout or the duties arising from law. 
At this point, whether the continuation of the employment relationship affects the existence of the working relationship should be examined. In the context of the absence of a working relationship, which is a condition of unemployment, the working relationship has a meaning under the law of performance (Leistungsrecht) in German Law. Unemployment benefits can be granted if only there is no employment within the meaning of performance law (BSG, Urteil vom 13.7.2006, in NZA$R R$, 2007: 384). In this sense, even if there is an employment relationship, it could be said that the working relationship is interrupted or terminated (BSG, Urteil vom 9. 9. 1993, in NZS, 1994: 142). Therefore, the condition regarding the absence of a working relationship must, as a rule, be assessed independently of the existence of an employment relationship. What is important is that the employee does not really work and does not get paid (Koch, 2017: § 23 Arbeitslosengeld I Rn. 6). If the insured no longer works, there is no working relationship in the sense of performance law unless a new working relationship is realized, or the previous working relationship has not started again (Mutschler, 2017: SGB III § 138 Rn. 9). However, the insured cannot be regarded as available more specifically fit to work in the context of these situations creating suspension of employment contract. Therefore, the phenomenon of unemployment should be examined separately within the framework all conditions in each suspension case. We would like to state that the meaning imposed on the working relationship in German Law in the context of performance law must also be valid in Turkish Law. Therefore, as long as there are other conditions sought for unemployment, the fact that the employment contract has been suspended is not an obstacle for unemployment. For example, it should be accepted that there is no working relationship in the sense of performance law in the presence of contractual suspension due to compulsory reasons which lasts more than one week, the period of free leave of the employee or seasonal employment contract (Regarding being entitled to unemployment benefit only via a new regulation, see Başterzi, 1996: 132; Bal Bektaş, 2016: 162-163). Thus, it cannot be propounded that the existence of employment relationship in these cases where the condition of availability is not damaged, eliminates the requirement of absence of working.

Another concept that needs to be considered in terms of the requirement of absence of working relationship is voluntary work. It is not possible to accept that the activities that are carried for an ideal purpose, rather than making a gain such as voluntary work, can be considered as obstacles to benefiting from unemployment benefit, and it is not possible to evaluate an activity which is only carried out as a hobby within the scope of working relationship (Baldschun, 2018: SGB III § 138 Rn. 27; Doğan Yenisey/Kabakcl, 2017: 107).

The avoidance of acceptance of the employee's work by the employer should also be examined in the context of the existence of a working relationship. As a rule, the employer's avoidance of accepting the work of the employee results in the default of the employer. According to article 408 of Turkish Code of Obligation, where the employer is at fault in preventing performance of the work or fails to accept its performance for other reasons, he remains obliged to pay the wage, but the employee is not obliged to make up the time thus lost. Since avoiding acceptance of the work requires employer to pay the wage as a result of default, it is not possible to accept unemployment here, unlike the suspension of employment contracts. However, if the employee chooses to terminate the employment contract due to the default of the employer, the unemployment requirement is accepted to be realized here (Bal Bektaş, 2016: 139).

\subsection{Willingness and Competence to Work}

Apart from the absence of a working relationship, the insured should be willing and able to work in order to establish the unemployment requirement. First of all, unemployment requires the employee to be in a position to end this situation. In German Law, receiving job replacement service by the Employment Agency alone is not considered sufficient in order for the insured to be willing to work, it is required for the unemployed to make efforts regarding job seeking. Failure by the insured person to fulfil this obligation results in the loss of unemployment benefit, which does not automatically terminate the right to benefit, only prevents the unemployed receive unemployment benefit unless he/ she makes such an effort (Mutschler, 2017: SGB III $\S 138$ Rn. 15). Under Turkish Law, it has been clearly stated that the insured unemployed must apply to işKUR and make a registration that he/ she is ready to take a new job. However, the fact that the unemployed insured cannot prove that he/ she has fulfilled the obligation to seek job other than the mediation of işKUR does not result in the termination of the benefit. Yet, it would be very appropriate for the purpose of the Law No. 4447 to impose an obligation on insured to make an effort to end the unemployment and to authorise işKUR to have a control over this by law.

In order to end unemployment, the unemployed insured should be available to the job replacement of iŞKUR while getting the job replacement service of işKUR. In German Law, availability has two aspects: subjective availability and objective availability. Subjective availability means that the unemployed is ready to work (Arbeitsbereitschaft); objective availability means that the unemployed is able to work (Arbeitsfähigkeit) (Koch, 2017: § 23 Arbeitslosengeld I Rn. 10). In the absence or termination of these, it is not possible to accept unemployment.

The will of the unemployed insured's readiness to work appears first in the declaration made to işKUR. Insured cannot restrict the declaration to be made to işKUR, as a matter of fact that the insured is available subjectively to the job replacement service. The fact that the insured is ready to work under certain employment types, perform certain jobs or 
professions are the limitations incompatible with subjective availability. Again, being ready to work cannot be conditional. The expectations of the insured in respect of the work, which is merely a wish, shall not impair the condition of being ready to work. Therefore, it is not possible to talk about unemployment only if there are limitations and conditions that are incompatible with subjective availability (Steinmeyer, 2017: SGB III § $139 \mathrm{Rn}$. 124-126). However, in order to be ready to work, this should be accepted as being ready to work in a suitable job (BSG, Urteil vom 24.5.1984, in NZA, 1985: 101). In article 52/1/a of Law No. 4447, it is stated that the unemployment benefit will be ceased in case of rejection of a job that is suitable for the profession, close to the wages and working conditions of the last work and within the boundaries of the municipal adjacent area of the residence without justified reason. Therefore, it cannot be stated that the condition of being ready for work has disappeared in terms of the işKUR's job replacement that is not a suitable job and the phenomenon of unemployment continues. In terms of the regulation, it is debatable on how the proximity of wage and other working conditions should be concretized. In German Law, some rates are determined by taking into consideration the duration of unemployment of the insured person in the special provision related to wage. According to this, in the first three months of unemployment, a reduction of more than $20 \%$ of the gainable wage and a reduction of more than $30 \%$ for the following three months cannot be considered suitable. From the seventh month of unemployment, a wage which is lower than the unemployment benefit is considered to be inappropriate (SGB III § 140). We think that it may be appropriate to take into account $20 \%$ or $30 \%$ in general, although it may not be appropriate to determine the rates varying according to the unemployment period since the periods of unemployment allowance are lower than those of German Law.

It should also be examined whether being over a certain age, in the context of the subjective availability condition, is effective in qualifying the insured as unemployed. In order to be entitled to unemployment benefit in our law, it is not possible to mention a general rule about age. However, at this point it can be mentioned that there is an indirect rule in terms of the insured persons who are entitled to pension.

There are some situations in which the insured cannot be regarded as able to work, remove the objective availability and hence there is no longer unemployment phenomenon. The fact that the insured is no longer able to work for any job, eliminates objective availability (Steinmeyer, 2017: SGB III $\S 139 \mathrm{Rn} .80$ ). While the types of appearance may be diverse, it is evident that, as we have already mentioned above, suspension of employment contracts arising from strikes, lockouts or the duties arising from the law eliminate the ability to work of the insured. Because Law Trade Unions and Collective Labour Agreements No. 6356 prohibits employees whose employment contracts are suspended due to a legal strike and lockout to work for another employer and otherwise employer contracts could be terminated by employers on just cause (Başterzi, 1996: 132). Again, in the case of a manoeuvre apart from the military duty or any mobilisation or any work duty arising from law, insured is not able to work for any other work by the nature of abovementioned situations. There has to be a meaning that the law maker only stated the suspension of employment contracts resulting from strike, lockout, duties arising from law in the relevant provision. Since the law maker has accepted an exception provision in the relevant regulation, its narrow interpretation is more appropriate than extending it to all suspension cases. Therefore, this provision is only comparatively applicable in terms of other suspension conditions which eliminate the condition of objective availability necessary for the establishment of unemployment phenomenon. For example, in case of employee's detention or arrest, it cannot be said that the employee could be employed during the period of detention or arrest. Again, for the period in which the insured is prohibited to work due to pregnancy, the conclusion is the same. Furthermore, in cases where the illness or disability of the insured constitutes an obstacle to the fulfilment of any the work that can be offered within the scope of the job which is suitable for the insured, the availability is eliminated (Steinmeyer, 2017: SGB III § 139 Rn. 81; For the opinion that the insured one is not able to work due to illness, maternity, military service and civil service and thus cannot be regarded as unemployed, see Bal Bektaş, 2016: 162). Otherwise, the suspension of the employment contract should not constitute an obstacle in terms of entitlement to unemployment benefit. At this point, we would like to note that the assessment in question is of a conceptual nature; we do not miss out that some of the insurance benefits made due to the appearance of certain suspension cases (i.e. benefit for temporary incapacity), eliminate unemployment benefit wholly or partially. Finally, apart from the suspension of employment contracts, in cases where the work and residence permit of foreign insured ends, unemployment phenomenon cannot exist due to the fact that there is no objective availability.

\section{TERMINATION OF EMPLOYMENT CONTRACTS BASED ON CERTAIN GROUNDS}

In order to be entitled to unemployment benefit under Law No. 4447, termination of employment contracts must be based on certain grounds. In the article 51 of the Law, these grounds are listed according to the numerus clausus principle. The main point here is that the insured person must not be culpable for the termination of employment contract (Sözer, 2017: 530). The first ground for the termination that entitles the unemployment benefit is the termination of the employment contracts by the employer with notice of termination. Termination of employment contracts by the employer immediately without giving any prior notice provided the wage corresponds to the notice period is paid in advance also entitles the unemployment benefit (Tuncay/ Ekmekçi, 2017: 662- 663; Saraç, 2012: 13; Bal Bektaş, 2016: 140). It should be noted that 
the fact that employers terminate the contracts immediately without giving notice or without a just cause- in case of irregular termination- also entitles unemployment benefit (Tuncay/ Ekmekçi, 2017: 663; Bal Bektaş, 2016: 140).

The termination of employment contracts for the just causes that cannot be attributed to the employee entitles to unemployment benefit, too. In fact, in article 51 of the Law, termination of employment contracts of the insured who are subject to Labour Law according to article $17 /$ I and III entitles the unemployment benefit and such provisions correspond to article 25/ I and III of Labour Law No. 4857. One question that may arise is whether the insured will be entitled to unemployment benefit in the immediate termination of the employment contracts within the scope of article 25/IV of Labour Law No. 4857 due to the detention or arrest of the employee. As it is known, this ground was not explicitly and separately regulated under article 17 of the abolished Labour Law No. 1475; it was regulated with subclause IV added in article 25 of Labour Law No. 4857. Since during the Labour Law No. 1475 terminations based on this ground was made according to article 17 of the same Law, the fact that this ground is regulated as a separate sub-clause in the Labour Law No. 4857 should not have a negative effect in terms of entitlement to unemployment benefit; we believe that the termination by the employer within the scope of Article 25/ IV of article 25 of the Labour Law No. 4857 shall also entitle the unemployment benefit (also see Tuncay/ Ekmekçi, 2017: 663). However, it should be noted that as long as the detention or custody continues, it is not possible for the insured to seek a job (see below for the explanation of availability). Therefore, unemployment benefit in case of termination within the scope of article 25/ IV of Labour Law is only provided after the detention/ custody end.

The termination of employment contracts by insured persons without just causes is a form of termination that does not entitle unemployment benefits. Similarly, termination of employment contracts by the mutual agreement of the employer and the insured person does not entitle insurance benefit. Because, in such cases unemployment is regarded voluntary (Bal Bektaş, 2016: 143-145). However, in German Law, both the employee's termination of employment contract without a significant reason in the sense of SGB III § 159, and the termination of employment contracts by mutual agreement do not prevent the entitlement to unemployment benefit; but the unemployed insured cannot benefit from it for the period of 12 weeks (Koch, 2018, Sperrzeit).

The automatic termination of employment contracts for definite term by the expiration of the term agreed is listed in article 51 of Law No. 4447 as to entitle insurance benefit. One problem that may be addressed here is whether or not the insured persons who have objected to the transfer of their employment contracts to the acquirer due to merger, split and type change of trade companies will be entitled to unemployment benefit. Article 178 of the Turkish Commercial Code No. 6102 includes the provision "if the employee objects, the employment contract is terminated at the end of the legal period of dismissal". Wording of the provision is convenient to make a deduction that the employment contracts terminate automatically in case of objection. Whereas there is no such provision in Law No. 4447 which entitles all the automatic terminations of employment contracts to insurance benefit. Only the expiration of the definite term contracts is accepted in this context. A scholar from Turkish Labour Law doctrine states that it is possible for the insured persons to be entitled to unemployment benefit by regarding the termination provided in article 178 of TCC as a dismissal by employer since the term "legal period of dismissal" evokes (Özkaraca, 2012: 140). We find this opinion rational.

It is stated in Turkish Labour Law doctrine that the insured persons cannot benefit from the unemployment insurance payment in case of unjust termination of definite term employment contracts before expiration date by employers since in this case they have right to demand the wage for the remaining term (see Bal Bektaş, 2016: 159). In our opinion, the insured persons should be entitled to unemployment benefit in this case, too. In fact, in this case insured persons may only demand the compensation amounted to the wage for the remaining term not the wage itself. This should not be considered as a restraint on the insurance benefit.

The termination of employment contracts within the scope of article 21 of the Privatization Law No. 4046 also entitles unemployment benefit (Art. 51 of Law No. 4447). The provision in question entitles job loss compensation to the workers whose employment contracts are terminated due to privatization. In fact, privatization practices do not terminate the employment contracts of the employees who work in institutions included in the scope of privatization itself, require the employer to terminate the contracts by giving notice. It is obvious that the insured persons whose employment contracts are terminated by their employer by giving notice are entitled the insurance payment (Art. 51 of Law No. 4447 . Also see Güzel/ Okur/ Caniklioğlu, 2016: 686). However, law maker chose to cease any hesitation by regulating this issue separately (Bal Bektaş, 2016: 161). Because in article 46 of Law No. 4447, those who received job loss compensation were excluded from unemployment insurance. However, the conditions for entitlement to job loss compensation are more severe than the conditions for entitlement to unemployment benefit; and the period of compensation is shorter than the period of unemployment benefit. The law maker who has taken in consideration this situation, has accepted the provisional article 1 of Law No. 4447 in spite of article 46 of Law No. 4447 in order to prevent the persons who received the job loss compensation to be in a more unfavourable position comparing the case they did not qualify for this compensation. According to the provisional article 1, insured persons who are entitled to work loss compensation and unemployment 
benefit at the same time cannot demand both payments. Job loss compensation must be paid primarily. However, it is also explicitly stated that the unemployment benefit will be paid but job loss compensation will be deducted from it, as long as the insured persons receiving job loss compensation cannot find a job during this period.

\section{HAVING WORKED FOR A CERTAIN PERIOD AND MET PREMIUM REQUIREMENTS}

As we have mentioned at the beginning, the severity of the conditions of entitlement to unemployment benefit in our current system is mainly due to the working and premium payment conditions for a certain period of time. Because in article 50 of Law no. 4447, insured unemployed are only entitled to unemployment benefit if they have been insured for 600 days in the last three years before the termination of the employment contract and they have paid unemployment insurance premium for this period and also, they have worked continuously for the last 120 days before the termination of the employment contract. In doctrine, it is stated that 3 separate conditions have to be met according to the relevant provision; first, the insured must have at least three years of insurance period to be entitled to the benefit; secondly, a premium of at least 600 days must be paid within this three-year period and lastly these 600 days premium must have been paid by having worked continuously for the last 120 days before the termination of the employment contract (Sözer, 2017: 527). We cannot conclude that the insured must have at least three years of insurance period in order to entitlement to unemployment benefit. The three-year period only refers to the period during which 600 days the unemployment insurance premium must have been paid. In terms of the condition of having worked continuously for the last 120 days, this must be accepted as the most important regulation that makes it difficult for the unemployed to be entitled to unemployment benefit (Özkaraca, 2002: 94). However, this condition has been facilitated with the Communiqué No. 3 on the Implementation of the Unemployment Insurance Law. According to article 2 of the Communiqué in question, "although the service contract is continuing; in cases of disease, free leave, disciplinary action, detention, custody which does not result in conviction, partial employment and interruption of work due to strike, lockout, events affecting general life, economic crisis, natural disasters in the last 120 days prior to the termination of the employment contract, the Social Security Institution records shall be taken as basis for the periods where the premium is not paid and such periods do not constitute an interruption when calculating 120 days. Again, in order to determine the entitlement, it is necessary to take reemployment lawsuit within the scope of article $20 \mathrm{ff}$. of Labour Law No. 4857 into account. According to article 50/ III of Law No. 4447, entitlement to unemployment benefit is determined based on the last day of the premiums paid due to the reemployment lawsuit and unemployment benefit is only provided for the time spent unemployed.

The existence of a condition similar to that in our country within the European Union member states is only available in Portugal (to have worked 600 days in the last two years) and Italy (to have worked 52 weeks in the last two years) (Limoncuoğlu, 2012: 385). In order to entitle Alg I, German Law requires insured to have worked for at least 12 months in the last two years- called "Anwartschaftszeit" (SGB III § 142).

In practice, the most important problem in terms of the aforementioned condition is the fact that employers declare insured work period less than the actual period and do not make the premium payment. While the correction of this situation is possible through an action for fixing of period of service; taking into account the length of the trial periods in our country, it is not possible to achieve the purpose expected from unemployment insurance in this way (Bal Bektaş, 2016: 180).

\section{APPLICATION TO TURKISH EMPLOYMENT AGENCY}

In case of the termination of employment contracts that entitles the unemployment benefit, employers are obliged to issue three copies of dismissal notice and send one of the copies to işKUR, hand one of the copies to the insured persons, keep one of the copies in the workplace within the 15 day-period (Art. 48/ IV of Law No. 4447). However, in additional article 1 of Law No. 4447, it is stated that the notifications made to Social Security Institution regarding the ending of the insurance coverage are substituted for the ones to be made to IŞKUR. Therefore, employers do not need to notify also işKUR. Within the scope of Law No. 5510 termination of employment contracts end the insurance relation and Social Security Institution must be notified about it no later than 10 days.

Insured persons who are unemployed and wishing to benefit from unemployment insurance payment must apply in person to IŞKUR directly or electronically with the dismissal notice issued by the employer within thirty days from the day following the termination of the employment contract (Art. 48/ V, 51/ I of Law No. 4447). With this requirement, it is highly probable that insured persons may be deprived of their rights in cases where the dismissal notice is not issued, or the employers issue it contrary to facts. In order to eliminate this risk to some extent, article 5 of the Communiqué on the Implementation of the Unemployment Insurance Law No. 3 states that the application for the insured unemployed person with his/ her petition and official ID will be sufficient in case the dismissal notice is not issued. On the other hand, no provision has been made for the insured unemployed, who is not entitled to unemployment benefit due to the fact that the dismissal notice has been issued contrary to facts. As a solution to this problem it is suggested that insured persons still should apply to işKUR and after applying should file an annulment action against the işKUR's decision declining the unemployment benefit 
(Sözer, 2017: 531). In our opinion, this approach is far from being a solution. Because the fact that the dismissal notice to be issued by employer is issued contrary to facts do not impair the işKUR's decision per se. In view of the current regulation, işKUR is bound by the ground for the termination stated in dismissal notice issued by the employer (Tuncay/ Ekmekçi, 2017: 666); thus, işKUR is not obliged to seek the real reason behind the termination of employment contracts. Current judgments of Court of Cassation are as follows: In a case against the employer either for reemployment or severance/ notice pay or the declaratory ruling as to determine the employment contract has been terminated on the grounds that entitle the insurance benefit, if the judge rules in favour of the insured unemployed, the insured may apply to işKUR for the retroactive insurance benefit, as long as the application to işKUR is made within the period of the payment to be made (See Court of Cassation, $9^{\text {th }}$ Civil Chamber, 9.11.2005, 7211/ 35435; Court of Cassation, $2^{\text {nd }}$ Civil Chamber, 23.1.2018, 20973/ 1142; Court of Cassation, $7^{\text {th }}$ Civil Chamber, 5.3.2015, 3316/3301, www.kazanci.com. Court of Cassation, $9^{\text {th }}$ Civil Chamber, 23.10.2007, 23578/ 31368, Bal Bektaş, 2016: 155). The interest to be processed from the date of the application to işKUR shall be requested from the employer within the context of general provisions (See Ekmekçi, 2011: 347. Also see Court of Cassation, $9^{\text {th }}$ Civil Chamber, 23.10.2007, 23578/31368, Bal Bektaş, 2016: 155). Although this practice is intended to redress the unemployment benefit, which the insured unemployed has been deprived of, it is far from achieving the goal of unemployment insurance which is to eliminate the negative consequences of unemployment (Also see Başterzi, 1996: 153; Bal Bektaş, 2016: 158). Because unemployment benefit is a payment that aims to provide sufficient income guarantee to provide minimum needs of the unemployed persons until they find a job. However, in this scenario, the insured persons get this payment quite late and perhaps after they find a job. Furthermore, it is unclear whether the agreement document concluded by the employer and the employee within the framework of the obligatory mediation provisions in the labour disputes adopted with the Labour Courts Law no. 7036 will have an effect on the entitlement of insurance benefit. In our opinion, the issues contained in dismissal notice are non-mediatable, the parties' agreements in this respect do not bind işKUR. In terms of de lege ferenda, the Agency should make the unemployment insurance payment relying on the statement of insured unemployed who has applied for it. In case of unwarranted payment, the Agency should demand it from the insured person in question (For other solutions suggested see Başterzi, 1996: 154; Tuncay, 2012: 13; Limoncuoğlu, 2012: 93). In fact, the Communiqué No. 3 on the Implementation of the Unemployment Insurance Law provides this solution when the dismissal notice is not issued by the employer at all. However, it should be noted that it is not easy to adopt this solution in the view of the current regulation.

Application to the Agency should be made within 30 days. The beginning of the 30 -day application period is determined as the day following the termination of the employment contract in article 48 of the Law No. 4447. However, the conditions entitling unemployment benefit are not limited to termination. For example, in cases where employment contracts for definite term terminate automatic with the expiration of the term, unemployment benefit is entitled. In our opinion, it would be more accurate to understand the expression of "the date of the termination of the employment contract" in article 48 as "the date when the employment contract ends". Also, the expression of "the date when the employment contract ends" require taking into account the date when the termination of the employer by giving notice or paying the wage corresponds to the notice in advance gets effective instead of the date of the declaration of termination (See Bal Bektaş, 2016: 191). However, in the event of irregular termination by the employer, the following day of the date of the declaration of the termination should be accepted as the beginning of the application. Regarding the insured persons who are not reemployed despite the ruling of annulment of the termination within the scope of article 21 of Labour Law No. 4857 , the date of the termination of the employment contract must be accepted as the date of the employer's declining to reemployment and 30-day application period has to be calculated accordingly.

The thirty-day application period is not qualified as a period of prescription (Bal Bektaş, 2016: 190). Because it is clearly stated in the article 48 of the Law the delayed time in application - except the force majeure-will be deducted from the total period entitled to receive unemployment benefit (Also see Court of Cassation, 10th Civil Chamber, 6.2.2007, 19646/ 1658, www.kazanci.com). The cases which may be accepted as force majeure are listed as exemplary in article 5 of the abovementioned Communiqué. For example, custody or detention without being sentenced are considered as force majeure.

In article 51 of Law No. 4447 insured persons demanding insurance benefit are required to make the application to the Agency in person and to register that they are ready to receive a new job. The Court of Cassation gives a negative answer to the question of whether the application can be made through the representative, for example attorney. The Supreme Court states that unemployment insurance includes the purpose of improving employment, as well as preventing the loss of income of the unemployed; In order to achieve this purpose, unemployed persons have to apply directly to the Agency in order to provide the organic bond with the Agency (Court of Cassation, Assembly of Civil Chamber, 3.5.2006, 10- 242/ 270; Court of Cassation, 10th Civil Chamber, 20.06.2006, 7506/ 9287, www.kazanci.com). In the doctrine, it was stated that the purpose of the provision was to prevent the application by notary or via mail to the Agency (Ekmekçi, 2009: 292). As a matter of fact, it was further stated that it should be possible to apply through an attorney since the possibility of applying to the Agency in electronic environment was accepted in 2008 (Ekmekçi, 2011: 341). 


\section{CONCLUSION}

Unemployment benefit is the most important tool in terms of providing the livelihood of 3 million 670 thousand people who are facing unemployment, which is one of the most important social risks especially in terms of our country. However, as stipulated in this study, the conditions of entitlement to this payment in our law are quite severe due to its nature. In our social security system, where the unemployment assistance is not regulated, it is necessary to at least facilitate the conditions of unemployment benefit and ensure that more unemployed persons benefit from it. When the savings in the Unemployment Insurance Fund is taken into consideration, the balance between gain and burden necessitates facilitating the conditions of unemployment benefit. In our opinion, it is necessary to adopt a wider approach, in particular in terms of addressing the definition of unemployment in a broader context and in the fact that unemployment is not specific to the termination of the employment contract, and even in terms of the types of termination of the employment contract. Again, the most important obstacle in terms of entitlement to unemployment benefit which is having worked for a certain period and premium requirements should be reconsidered.

\section{REFERENCES}

Bal Bektaş, Ö. (2016). İşsizlik Sigortası. Ankara.

Baldschun, K. (2018). SGB III § 138 in SGB II/SGB III Grundsicherung und Arbeitsförderung, 71. EL, München.

Başterzi, S. (1996). İşsizlik Sigortası. Ankara.

Brand, J. (2018). SGB III § 138 Arbeitslosigkeit in Sozialgesetzbuch Arbeitsförderung -SGBIII- 8. Aufl., München.

Caniklioğlu, N. (2011). 6111 Sayılı Kanunla İşsizlik Sigortası Kanununda Yapılan Değişiklikler. Toprak Işveren, 89: $10-21$.

Doğan Yenisey, K. \& Kabakcı, M. (2017). Gönüllü Emeği ve İş Hukuku, İstanbul.

Ekmekçi, Ö. (2009). Sosyal Sigortaların Genel Hükümleri ve Türleri Açısından Yargıtayın 2006 Kararlarının Değerlendirilmesi. Yargıtayın iş Hukuku ve Sosyal Güvenlik Hukuku Kararlarının Değerlendirilmesi 2006: 284- 338.

Ekmekçi, Ö. (2011). Sosyal Sigortaların Genel Hükümleri ve Türleri Açısından Yargıtayın 2009 Kararlarının Değerlendirilmesi. Yargıtayın İ̧̧ Hukuku ve Sosyal Güvenlik Hukuku Kararlarının Değerlendirilmesi 2009: 317- 409.

Güzel, A. \& Okur, A. R. \& Caniklioğlu, N. (2016). Sosyal Güvenlik Hukuku, 16. Baskı. İstanbul.

Hekimler, A. (2008). Almanya'da İşsizlik Sigortası Alanındaki Güncel Gelişmeler Işığında Türkiye İçin Gözlemler, Legal iş Hukuku ve Sosyal Güvenlik Hukuku Dergisi, 18: 537-550.

https://beck-online.beck.de

Koch, U. (2017). § 23 Arbeitslosengeld I in Arbeitsrechts-Handbuch, 17. Aufl., München.

Koch, U. (2018). Sperrzeit in Arbeitsrecht von A-Z, 22. Aufl., München.

Limoncuoğlu, S. A. (2012). İşsizlik Sigortası ve Uygulama Sorunları. Sicil iş Hukuku Dergisi, 26: 84- 98.

Mutschler,B. (2017). SGB III § 138 Arbeitslosigkeit in Kommentar zum Sozialrecht, 5. Aufl., München.

Özkaraca, E. (2002). İşsizlik Sigortası Kapsam ve Yardımları (Unpublished Master's Thesis). Marmara University, İstanbul, Turkey.

Özkaraca, E. (2012). 6102 Sayılı Türk Ticaret Kanunu'na Göre Şirketlerin Birleşmesi, Bölünmesi ve Tür Değiştirmesinin İş Hukukuna Etkileri. İş Hukukunda Güncel Sorunlar (2), Kadir Has Üniversitesi Hukuk Fakültesi, 25 Mayıs 2012 İstanbul: 103- 172.

Saraç, C. (2012). İşsizlik Sigortası Edim Koşulları. Dokuz Eylül Üniversitesi Hukuk Fakültesi Dergisi, 13: 1-26.

Sözer, A. N. (2017). Türk Sosyal Sigortalar Hukuku, 3. Baskı. İstanbul.

Steinmeyer, H. (2017). SGB III § 139 Sonderfälle der Verfügbarkeit in Kündigungsrecht, 5. Aufl., München.

Süzek, S. (2018). İş Hukuku, 16. Baskı. İstanbul.

Tuncay, A. C. (2001). İşsizlik Sigortasının Kapsamı ve İşsizlik Ödeneği. Çimento İşveren Dergisi, 1: 3- 20.

Tuncay, A. Can \& Ekmekçi, Ö. (2017). Sosyal Güvenlik Hukuku Dersleri, 19. Baskı. İstanbul.

www.kazanci.com 